\title{
ANTIBIOTICS USED AS ANTI-INFLAMMATORY AND IMMUNOMODULATORY AGENTS IN DERMATOLOGICAL DISORDERS
}

\author{
S. Showkath Ali1 ${ }^{1}$ T. Praveena ${ }^{2}$, M. Madhavi Lata ${ }^{3}$,Mastan Saheb ${ }^{4}$ \\ ${ }_{1}^{1}$ Assistant Professor, Department of DVL, SRMC, Nandyal, Andhra Pradesh, India. \\ ${ }^{2}$ Assistant Professor, Department of DVL, SRMC, Nandyal, Andhra Pradesh, India. \\ 3 Professor, Department of DVL, SRMC, Nandyal, Andhra Pradesh, India. \\ ${ }^{4}$ Professor, Department of DVL, SRMC, Nandyal, Andhra Pradesh, India.
}

\section{BACKGROUND}

ABSTRACT

Antibiotics are the drugs used for killing or inhibiting growth and multiplication of infectious organisms. Antibiotics are commonly prescribed for treatment of infections. However, antibiotics have immunomodulatory and anti-inflammatory properties and can be used for various non-infectious dermatoses. Dermatologists routinely prescribe antibiotics in treatment of various non-infectious disorders. Tetracyclines can be used in Bullous pemphigoid, Acne vulgaris, Rosacea, Hidradenitis suppurativa, Pyoderma gangrenosum, Linear IgA disease and Dermatitis herpetiformis. ${ }^{1}$

This clinical study will review anti-inflammatory and immunomodulatory effects of Tetracyclines used in 15 patients of bullous pemphigoid (04), acne vulgaris (06), pyoderma gangrenosum (03) and rosacea (02) along with vitamin B3 (niacinamide). These drugs can be used as steroid sparing agents when other comorbidities are present in elderly patients.

\section{KEY WORDS}

Antibiotics, Anti-Inflammatory, Immunomodulatory, Dermatological Disorders.

HOW TO CITE THIS ARTICLE: Ali SS, Praveena T, Lata MM, et al. Antibiotics used as anti-inflammatory and immunomodulatory agents in dermatological disorders. J. Evolution Med. Dent. Sci. 2018;7(34):3804-3807, DOI: 10.14260/jemds/2018/853

\section{BACKGROUND}

Antibiotics are chemicals derived from microorganisms that have the capacity to kill other microorganisms (Bacteria, virus, fungi and parasite) or inhibit their growth. In routine clinical practise, antibiotics are chiefly used to eliminate various microorganisms (Bacteria, viruses and parasites). Many antibiotics were found to have anti-inflammatory properties. $^{2-5}$

\section{Tetracyclines}

The tetracyclines are broad-spectrum antibiotics and comprises of four main drugs Tetracycline [T], doxycycline [D], minocycline [M] and lymecycline [L]). These antibacterial agents are indicated in a wide range of infections including Treponema pallidum (Syphilis), Borrelia burgdorferi, Borrelia garinii (Lyme disease), Coxiella burnetii (Q fever), Rickettsia rickettsii (Rocky Mountain spotted fever) and Yersinia pestis (Plague). Their antibiotic effect is by binding to the $30 \mathrm{~S}$ subunit of bacterial ribosomes and halting protein synthesis. However, many tetracyclines have anti-inflammatory properties. $^{6-7}$ Alteration of Tetracycline structure may alter phototoxic potential, which is dose related phenomenon, more common with Doxycycline $>$ Tetracycline $>$ Minocycline.

In dermatology, Tetracyclines are commonly used in Acne vulgaris. More recently, biologic actions affecting inflammation, proteolysis, angiogenesis, apoptosis, metal chelation, ionophoresis and bone metabolism have been

'Financial or Other Competing Interest': None.

Submission 16-05-2018, Peer Review 01-08-2018,

Acceptance 09-08-2018, Published 20-08-2018.

Corresponding Author:

Dr. S. Showkath Ali,

Department of DVL,

SRMC \& GH, NH-44,

Nandyal-518501, Andhra Pradesh, India.

E-mail: shoukath2128@gmail.com

DOI: $10.14260 /$ jemds/2018/853

\section{(c) (1) $(9)$}

researched. The therapeutic effects of tetracycline include rosacea, bullous dermatoses, neutrophilic dermatoses, pyoderma gangrenosum, sarcoidosis, aortic aneurysms, cancer metastasis, periodontitis and autoimmune disorders such as rheumatoid arthritis and scleroderma.

Anti-inflammatory properties include: 1 . Inhibition of the production of neutrophil chemoattractants by P. acnes; 2 . Inhibition of neutrophil migration; 3. Inhibitory activity against granuloma formation in vitro, due to protein kinase $\mathrm{C}$ inhibition; 4. Inhibition of multiple matrix metalloproteinases (MMP); 5. Down regulation of cytokines of innate immune response; and 6. A possible scavenger effect against reactive oxygen species (ROS). ${ }^{6-7}$

\begin{tabular}{|c|c|c|c|}
\hline $\begin{array}{l}\text { Disease/ } \\
\text { Condition }\end{array}$ & Agent & $\begin{array}{c}\text { Mechanism of Action } \\
\text { for Anti-inflammatory } \\
\text { Property }\end{array}$ & Dose \\
\hline Acne vulgaris & $\mathrm{D}, \mathrm{M}$ & \begin{tabular}{|} 
Inhibits IL-8 ${ }^{[8]}$ \\
Inhibits MMP-1[9] \\
ROS scavenging $10-11]$ \\
Inhibiting bacterial \\
products that stimulate \\
inflammation $12-13)$ \\
\end{tabular} & \\
\hline $\begin{array}{l}\text { Confluent and } \\
\text { reticulated } \\
\text { papillomatosis }{ }^{[14]} \\
\text { Granulomatous } \\
\text { diseases }^{[15]}\end{array}$ & $\mathrm{D}, \mathrm{M}$ & $\begin{array}{l}\text { Inhibit } \mathrm{T} \text {-cell } \\
\text { proliferation and } \\
\text { granuloma } \\
\text { formation[16] }\end{array}$ & $\begin{array}{l}\mathrm{D}-200 \mathrm{mg} / \text { day } \\
\mathrm{M}-200 \mathrm{mg} / \text { day }\end{array}$ \\
\hline $\begin{array}{l}\text { Immunobullous } \\
\text { diseases }^{[17-19]}\end{array}$ & $\begin{array}{c}\mathrm{T}, \mathrm{M} \\
\mathrm{D}\end{array}$ & $\begin{array}{l}\text { Inhibit MMP and mast } \\
\text { cell activation }{ }^{[20]}\end{array}$ & $\begin{array}{l}\mathrm{T}-1500 \mathrm{mg} / \text { day } \\
\mathrm{M}-100 \mathrm{mg} / \text { day } \\
\mathrm{D}-100 \mathrm{mg} / \text { day }\end{array}$ \\
\hline $\begin{array}{c}\text { Neutrophil } \\
\text { disorders [21,[22] }\end{array}$ & $\mathrm{D}, \mathrm{M}$ & $\begin{array}{c}\text { Inhibit IL-8 and } \\
\text { neutrophil activation }{ }^{[23]}\end{array}$ & $\begin{array}{c}\text { D-200 mg daily } \\
\text { M-200-300 } \\
\text { mg/day }\end{array}$ \\
\hline Rosacea $^{[24]}$ & $\mathrm{D}, \mathrm{M}$ & \begin{tabular}{|c|} 
Decreases ROS \\
damage \\
Act on VEGF, iNOS and \\
NO and \\
preventing excessive \\
vascular dilatation and \\
angiogenesis in \\
rosacea $^{[25]}$ \\
\end{tabular} & $\begin{array}{l}\mathrm{D}-100 \mathrm{mg} / \text { day } \\
\mathrm{M}-100 \mathrm{mg} / \text { day }\end{array}$ \\
\hline
\end{tabular}




\begin{tabular}{|c|c|c|c|}
\hline & & $\begin{array}{l}\text { Inhibit granuloma } \\
\text { formation in vitro }{ }^{[11]}\end{array}$ & \\
\hline Lichen planus ${ }^{[26]}$ & T, D & $\begin{array}{l}\text { Inhibition of the } \\
\text { T-lymphocyte } \\
\text { response }\end{array}$ & $\begin{array}{l}\text { T-500 mg BD, } \\
\text { D-100 mg BD. }\end{array}$ \\
\hline $\begin{array}{l}\text { Pityriasis } \\
\text { lichenoides }{ }^{[28]}\end{array}$ & $\mathrm{T}$ & $\begin{array}{l}\text { Inhibition of the } \\
\text { T-lymphocyte } \\
\text { response }{ }^{[18]}\end{array}$ & 500 mg BD \\
\hline $\begin{array}{c}\text { Prurigo } \\
\text { pigmentosa }{ }^{[29,30]}\end{array}$ & $\mathrm{D}, \mathrm{M}$ & $\begin{array}{l}\text { Inhibits the migration } \\
\text { and/or function of } \\
\text { neutrophils }{ }^{[23]}\end{array}$ & $\begin{array}{l}\mathrm{D}-200 \mathrm{mg} / \text { day } \\
\mathrm{M}-200 \mathrm{mg} / \text { day }\end{array}$ \\
\hline \multicolumn{4}{|c|}{$\begin{array}{l}\text { Table 1. Indications of Tetracyclines in Dermatology as Anti- } \\
\text { Inflammatory Drugs }\end{array}$} \\
\hline
\end{tabular}

BD: Twice a day, OD: Once a day, D: Doxycycline, M: Minocycline, ROS: Reactive oxygen species, NO: Nitric oxide, iNOS: Inducible Nitric Oxide Synthase, VEGF: Vascular Endothelial Growth Factor, IL: Interleukin, MMP: Matrix Metalloproteinase, T: Tetracycline, L: Lymecycline

Niacin (Vit $\mathrm{B}_{3}$ )

Niacin is an essential dietary constituent, the deficiency of which leads to pellagra. In the body nicotinic acid is converted to niacinamide, which functions as a coenzyme that accepts hydrogen ions in oxidation-reduction reactions essential for tissue respiration.

Anti-inflammatory effect of niacinamide, it inhibits poly(ADP-ribose) polymerase-1 (PARP-1), a nuclear enzyme that enhances nuclear factor- $\mathrm{\kappa B}$ transcription. Inhibition of this pathway alters leukocyte chemotaxis by dysregulation of adhesion factors necessary for migration. ${ }^{31}$ Niacinamide reduces lysosomal enzyme release and stabilises leukocytes by inhibiting cAMP PDE, and also inhibits lymphocytic transformation and the production of antibodies. This latter mechanism makes the drug particularly useful for the treatment of antibody-mediated diseases (e.g. bullous pemphigoid).

In immunobullous disorders, one randomised, open-label trial suggested comparable efficacy and fewer adverse effects using the combination of nicotinamide (niacinamide) and tetracycline compared with prednisone as first-line therapy for bullous pemphigoid.32 Another small review suggested that the combination of nicotinamide and tetracycline may be an effective alternative to corticosteroids in pemphigus foliaceus and pemphigus erythematosus and as a 'steroidsparing' adjuvant rather than corticosteroid alternative in pemphigus vulgaris. ${ }^{32}$ Assessment of clinical response to niacinamide alone in treating autoimmune blistering disorders and erythema elevatum diutinum has clearly been complicated by concomitant tetracycline or erythromycin use in these studies. It has been proposed that the antiinflammatory properties of these antibacterial agents may function synergistically with nicotinamide in the treatment of diseases with excessive PMN chemotaxis. ${ }^{33}$ Because tetracycline alone has been reported to clear bullous pemphigoid, it is difficult to assess nicotinamide's exact contribution in treatment of bullous diseases. 34 However, one case of localised bullous pemphigoid responding to niacinamide alone has been reported. ${ }^{35}$

\section{Aim}

Treatment of bullous pemphigoid, pyoderma gangrenosum, acne vulgaris and rosacea with doxycycline and niacinamide.

\section{MATERIALS AND METHODS}

An open trial on 15 patients treated with Doxycycline and niacinamide. Doxycycline, with a starting dose of $100 \mathrm{mg}$ bd, which was then reduced by $100 \mathrm{mg} /$ day. The initial dosage $500 \mathrm{mg}$ bd of niacinamide was maintained throughout the study period, from February 2017 to November 2017. When a relapse occurred, the patients were treated again with the last effective dosage. When the patient did not respond to medication (failure to respond with development of 5 or more lesions per day), prednisolone was added in bullous pemphigoid and pyoderma gangrenosum patients, whereas in acne vulgaris and Rosacea patients, retinoids were added.

Exclusion criteria was patients with hepatic disease, kidney diseases, cardiac disease, pregnant women, nursing mothers and patients allergic to Doxycycline and niacinamide. Detail history of the patients with vitals was recorded at time of initial treatment. Clinical examination, blood investigations and adverse events from treatment were recorded at 0, 4, 8 and 12 weeks. Then patients were followed every three months once. The severity of disease was based on body surface involvement and active lesions like blisters, wheals, papules, pustules, nodules, ulcer, erosion and crusts. Complete improvement (CR) was recorded as > $90 \%$ improvement in lesions, partial improvement (PR) as 50-90\% improvement in lesions, no response (NR) as < 50\% improvement and progressive disease (PD) as those who did not respond to treatment.

\section{Monitoring}

Blood investigations and vital parameters were recorded throughout the study. Child bearing female age group were strictly monitored for pregnancy test. Patients were monitored for any adverse reactions with medications.

\section{RESULTS}

15 patients were treated in the clinical study, 8 were males and 7 were females. The mean disease duration prior to onset of treatment was 5.3 months (Range 0 - 36 months). Clinically, bullous pemphigoid was diagnosed and confirmed with skin biopsy and histopathology report. Four patients of bullous pemphigoid were treated with Doxycycline and niacinamide along with topical treatment. Three patients had good improvement and one patient did not come for followup defaulted.

Three patients with pyoderma gangrenosum diagnosed based on clinical, histological features and treated with DOX + NIA along with topical treatment, one had complete clearance of lesions, one patient had partial clearance and treatment continued for six months. One patient with no improvement with medication prednisolone $30 \mathrm{mg} /$ day was added after study period.

Six patients with acne vulgaris with grade II and III were treated with DOX + NIA along with topical medication, five patients had complete clearance, whereas one patient with grade III acne vulgaris improved partially and subsequently oral isotretinoin $10 \mathrm{mg}$ /day was started. Two patients with papulopustular rosacea was treated with partial clearance and subsequently started with oral retinoids.

The average duration of complete improvement was 8.0 weeks, while those with partial improvement had complete improvement at 12 weeks. Severity of disease was ranged from $10 \%$ to $40 \%$ of BSA. 10 patients of study had less than 
$15 \%$ involvement of BSA. Five patients with severe disease involvement, i.e. $>15 \%$ of BSA. No adverse drug reactions were observed with doxycycline and niacinamide in all 15 patients.

\begin{tabular}{|c|c|c|c|c|c|}
\hline 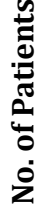 & 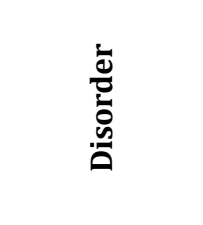 & 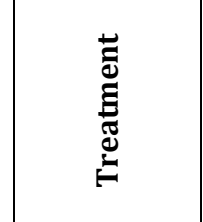 & 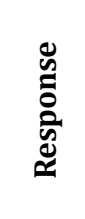 & 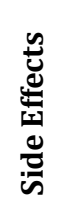 & 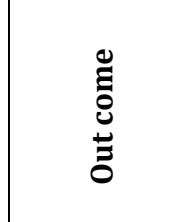 \\
\hline \multirow[t]{2}{*}{4} & $\begin{array}{c}\text { Bullous } \\
\text { pemphigoid }\end{array}$ & $\begin{array}{c}\text { Doxycycline }+ \\
\text { Niacinamide }\end{array}$ & CR-3 & No & No relapse \\
\hline & & & CR-1 & No & $\begin{array}{l}\text { After } 2 \\
\text { months } \\
\text { patient } \\
\text { default }\end{array}$ \\
\hline \multirow[t]{3}{*}{3} & $\begin{array}{c}\text { Pyoderma } \\
\text { gangrenosum }\end{array}$ & $\begin{array}{c}\text { Doxycycline }+ \\
\text { Niacinamide } \\
\end{array}$ & CR-1 & No & No relapse \\
\hline & & & PR-1 & No & \begin{tabular}{|c|} 
Treatment \\
continued till \\
6 months \\
\end{tabular} \\
\hline & & & NR-1 & No & \begin{tabular}{|c} 
Prednisolone \\
$30 \mathrm{mg} /$ day \\
started at $8^{\text {th }}$ \\
week
\end{tabular} \\
\hline \multirow[t]{2}{*}{6} & Acne vulgaris & $\begin{array}{c}\text { Doxycycline }+ \\
\text { Niacinamide } \\
\end{array}$ & CR-5 & No & No relapse \\
\hline & & & PR-1 & No & $\begin{array}{c}\text { Subsequently } \\
\text { oral } \\
\text { isotretinoin } \\
10 \mathrm{mg} / \text { day at } \\
10^{\text {th }} \text { week }\end{array}$ \\
\hline 2 & Rosacea & $\begin{array}{c}\text { Doxycycline }+ \\
\text { Niacinamide }\end{array}$ & PR-2 & No & $\begin{array}{c}\text { Subsequently } \\
\text { oral } \\
\text { isotretinoin } \\
10 \mathrm{mg} / \text { day } \\
\text { started at } \\
10^{\text {th }} \text { week } \\
\end{array}$ \\
\hline
\end{tabular}

Complete improvement (CR) - > 90\% decrease in lesions; Partial improvement (PR) - 50 - 90\% decrease in lesions. No improvement (NR) $-<50 \%$ improvement

\section{DISCUSSION}

The mainstay of treatment for bullous pemphigoid and pyoderma gangrenosum is systemic corticosteroids. However, some patients are elderly and have concurrent diabetes mellitus, hypertension, congestive cardiac failure and osteoporosis, which maybe aggravated by corticosteroid therapy. The use of immunosuppressive drugs as steroid sparing agents is also associated with serious side-effects which are poorly tolerated by the elderly.

Berk and Lorincz(36) first reported success in the treatment of bullous pemphigoid with a combination of tetracycline (upto $2 \mathrm{~g} /$ day) and nicotinamide (upto 2.5 $\mathrm{g} /$ day) in 1986 . Fivenson et $\mathrm{al}^{32}$ published the results of randomised controlled study, which compared this combination treatment with prednisone. Of 12 patients on tetracycline and nicotinamide, there were five complete responders, five partial responders and one non-responder.
Kolbach et al(37) reported improvement with decrease of blister formation within 6 - 8 weeks in 7 patients treated with tetracycline and nicotinamide. In our study, improvement was observed within 8 weeks. Hornschuh et al(4) treated 16 patients with oral tetracycline and nicotinamide combined with the initial application of $0.5 \%$ clobetasol propionate cream. Complete improvement of skin lesions was seen in 13 patients within 4 weeks of treatment. In our study 4 patients with bullous pemphigoid was treated with Doxycycline 100 mg BD and Niacinamide $500 \mathrm{mg}$ BD, three patients had complete improvement after 12 weeks treatment, one patient had complete improvement after 8 weeks, but lost for followup by default.

The successful use of minocycline in pyoderma gangrenosum A report of seven cases and review of the literature by Berth-Jones J22. Successful treatment of Sweet's syndrome with doxycycline by Joshi $\mathrm{RK}^{21}$, In our study 3 patients with Pyoderma gangrenosum treated with DOX + NIA, of which 1 had complete clearance of lesions, 1 patient had partial clearance at the end of 12 weeks so treatment continued with DOX + NIA for three months and one patient had poor response so oral prednisolone $30 \mathrm{mg} /$ day was started at 8 week.

Six patients with acne vulgaris were treated, of which 5 patients had complete clearance of lesions and one patient had partial response subsequently oral retinoids started with $10 \mathrm{mg} /$ day at 12 weeks.

Sneddon performed a double-blind, placebo-controlled trial of tetracycline for rosacea in 1966 to evaluate its effects on the "erythematous and papular type" and the "pustular form" of rosacea.(38) The second-generation tetracyclines are similarly effective for rosacea, In our study, two patients with papulopustular rosacea was treated with partial clearance of lesions at 12 weeks, subsequently systemic retinoids started.

\section{CONCLUSION}

Treatment with Doxycycline and niacinamide as antiinflammatory and immunomodulatory agents for dermatological disorders is effective in 10 out of 15 patients treated. This is an effective steroid sparing treatment regimen in the elderly patients with other comorbidities. Doxycycline with Niacinamide can be used in some immune disorders of dermatological conditions. In our study, patients with more localised disease respond better than those with widespread disease. Doxycycline and Niacinamide have lesser gastrointestinal side effects and a more convenient dosing with more compliance of patients.

\section{REFERENCES}

[1] Sapadin AN, Fleischmajer R. Tetracyclines: nonantibiotic properties and their clinical implications. J Am Acad Dermatol 2006;54(2):258-65.

[2] Reed J, Wilkinson J. Subcorneal pustular dermatosis. Clin Dermatol 2000;18(3):301-13.

[3] Nishijima C, Hatta $N$, Inaoki $M$, et al. Urticarial vasculitis in systemic lupus erythematosus: fair response to prednisolone/dapsone and persistent hypocomplementemia. Eur J Dermatol 1999;9(1):54-6.

[4] Eiser AR, Singh P, Shanies HM. Sustained dapsone-induced remission of hypocomplementemic 
urticarial vasculitis--a case report. Angiology 1997;48(11):1019-22.

[5] Labro MT. Anti-inflammatory activity of macrolides: a new therapeutic potential? J Antimicrob Chemother 1998;41 Suppl B:37-46.

[6] Scaglione F, Rossoni G. Comparative anti-inflammatory effects of roxithromycin, azithromycin and clarithromycin. J Antimicrob Chemother 1998;41 Suppl B:47-50.

[7] Kus S, Yucelten D, Aytug A. Comparison of efficacy of azithromycin vs. doxycycline in the treatment of acne vulgaris. Clin Exp Dermatol 2005;30(3):215-20.

[8] Monk E, Shalita A, Siegel DM. Clinical applications of non-antimicrobial tetracyclines in dermatology. Pharmacol Res 2011;63(2):130-45.

[9] Griffin MO, Fricovsky E, Ceballos G, et al. Tetracyclines: a pleitropic family of compounds with promising therapeutic properties. Review of the literature. Am J Physiol Cell Physiol 2010;299(3):C539-48.

[10] Sarici G, Cinar S, Armutcu F, et al. Oxidative stress in acne vulgaris. J Eur Acad Dermatol Venereol 2010;24(7):763-7.

[11] Skidmore R, Kovach R, Walker C, et al. Effects of subantimicrobial-dose doxycycline in the treatment of moderate acne. Arch Dermatol 2003;139(4):459-64.

[12] Webster GF, Leyden JJ, McGinley KJ, et al. Suppression of polymorphonuclear leukocyte chemotactic factor production in Propionibacterium acnes by subminimal inhibitory concentrations of tetracycline, ampicillin, minocycline, and erythromycin. Antimicrob Agents Chemother 1982;21(5):770-2.

[13] Bahrami F, Morris DL, Pourgholami MH. Tetracyclines: drugs with huge therapeutic potential. Mini Rev Med Chem 2012;12(1):44-52.

[14] Rao TN, Guruprasad P, Sowjanya CH, et al. Confluent and reticulated papillomatosis: successful treatment with minocycline. Indian J Dermatol Venereol Leprol 2010;76(6):725.

[15] Bachelez H, Senet P, Cadranel J, et al. The use of tetracyclines for the treatment of sarcoidosis. Arch Dermatol 2001;137(1):69-73.

[16] Webster GF, Toso SM, Hegemann L. Inhibition of a model of in vitro granuloma formation by tetracyclines and ciprofloxacin. Involvement of protein kinase C. Arch Dermatol 1994;130(6):748-52.

[17] McCarty M, Fivenson D. Two decades of using the combination of tetracycline derivatives and niacinamide as steroid-sparing agents in the management of pemphigus: defining a niche for these low toxicity agents. J Am Acad Dermatol 2014;71(3):475-9.

[18] Le Sache-de Peufeilhoux L, Raynaud E, Bouchardeau A, et al. Familial benign chronic pemphigus and doxycycline: a review of 6 cases. J Eur Acad Dermatol Venereol 2014;28(3):370-3.

[19] Shan XF, Zhang FR, Tian HQ, et al. A case of linear IgA dermatosis successfully treated with tetracycline and niacinamide. Int J Dermatol 2016;55(4):e216-7.
[20] Kazandjieva J, Kamarashev J, Hinkov G, et al. Rifampicin and psoriasis. Akt Dermatol 1997;23:78-81.

[21] Joshi RK, Atukorala DN, Abanmi A, et al. Successful treatment of Sweet's syndrome with doxycycline. $\mathrm{Br} \mathrm{J}$ Dermatol 1993;128(5):584-6.

[22] Berth-Jones J, Tan SV, Graham-Brown RAC, et al. The successful use of minocycline in pyoderma gangrenosum - a report of seven cases and review of the literature. J Dermatol Treat 1989;1(1):23-5.

[23] Khurana S, Singh P. Rifampin is safe for treatment of pruritus due to chronic cholestasis: a meta-analysis of prospective randomized-controlled trials. Liver Int 2006;26(8):943-8.

[24] Baldwin HE. Diagnosis and treatment of rosacea: state of the art. J Drugs Dermatol 2012;11(6):725-30.

[25] Perret LJ, Tait CP. Non-antibiotic properties of tetracyclines and their clinical application in dermatology. Australas J Dermatol 2014;55(2):111-8.

[26] Hantash BM, Kanzler MH. The efficacy of tetracycline antibiotics for treatment of lichen planus: an open-label clinical trial. $\mathrm{Br} \mathrm{J}$ Dermatol 2007;156(4):758-60.

[27] Kloppenburg M, Verweij CL, Miltenburg AM, et al. The influence of tetracyclines on T cell activation. Clin Exp Immunol 1995;102(3):635-41.

[28] Piamphongsant T. Tetracycline for the treatment of pityriasis lichenoides. $\mathrm{Br} \quad \mathrm{J}$ Dermatol 1974;91(3):319-22.

[29] Kim TI, Choi JW, Jeong KH, et al. Pustular prurigo pigmentosa treated with doxycycline. J Dermatol 2016;43(8):965-6.

[30] Matsumoto C, Kinoshita M, Baba S, et al. Vesicular prurigo pigmentosa cured by minocycline. J Eur Acad Dermatol Venereol 2001;15(4):354-6.

[31] Fivenson DP. The mechanisms of action of nicotinamide and zinc in inflammatory skin disease. Cutis 2006;77(1 Suppl):5-10.

[32] Fivenson DP, Breneman DL, Rosen GB, et al. Nicotinamide and tetracycline therapy of bullous pemphigoid. Arch Dermatol 1994;130(6):753-8.

[33] Chaffins ML, Collison D, Fivenson DP. Treatment of pemphigus and linear IgA dermatosis with nicotinamide and tetracycline: a review of 13 cases. J Am Acad Dermatol 1993;28(6):998-1000.

[34] Pereyo NG, Davis LS. Generalized bullous pemphigoid controlled by tetracycline therapy alone. J Am Acad Dermatol 1995;32(1):138-9.

[35] Honl BA, Elston DM. Autoimmune bullous eruption localized to a breast reconstruction site: response to niacinamide. Cutis 1998;62(2):85-6.

[36] Berk MA, Lorincz AL. The treatment of bullous pemphigoid with tetracycline and niacinamide. A preliminary report. Arch Dermatol 1986;122(6):6704.

[37] Kolbach DN, Remme JJ, Bos WH, et al. Bullous pemphigoid successfully controlled by tetracycline and nicotinamide. Br J Dermatol 1995;133(1):88-90.

[38] Sneddon IB. A clinical trial of tetracycline in rosacea. Br J Dermatol 1966;78(12):649-52. 